\author{
Kaja Klimek \\ Katedra Porównawczych Studiów Cywilizacji \\ Wydział Filozoficzny \\ Uniwersytet Jagielloński
}

\title{
Życie to kaisha. Specyficzne rozumienie japońskiej przedsiębiorczości
}

Gdy mowa o Japonii, punktem wyjścia analizy specyfiki jej kultury, prawa czy ekonomii - bo z tym najbardziej wiąże się kwestia przedsiębiorczości - musi być myśl konfucjańska. Myśl chińska, a wraz z nią tradycja konfucjańska leżą bowiem u podstaw japońskiej wizji świata i jego uporządkowania. Gdy mówimy o korzeniach cywilizacji europejskiej, odwołujemy się przede wszystkim do dwóch: judeochrześcijańskiego, którego dziedzictwem jest filar religijny cywilizacji europejskiej, oraz kultury grecko-helleńskiej, która Europie dała podbudowę filozoficzną. W przypadku Japonii - której plemienna przeszłość sprzed VII w., czyli momentu otwarcia na zewnątrz i początku przejmowania od Chińczyków konfucjańskiej organizacji społecznej, chowa się w mrokach - głównym filarem kulturowym był konfucjanizm.

Otwarcie na Chiny i proces przejmowania ich dorobku rozpoczęte w VII w. przyniosły Japonii pismo, organizację społeczną oraz zespół zasad i norm moralnych, które zorganizowały życie społeczeństwa. Zwracając uwagę na kulturowe różnice, jakie czynią japońską przedsiębiorczość tak odmienną od zachodniej, największy nacisk należy położyć na przejęte od Chińczyków zasady organizacji rodziny, odmienny stosunek do prawa i moralności oraz specyficzną rolę etyki konfucjańskiej.

Kluczowe jest stwierdzenie, że sposób organizacji rodziny, który narzucił Chińczykom konfucjanizm, a który Japończycy przejęli od kontynentalnych sąsiadów, w znaczący sposób przekłada się na organizację kaisha - japońskiej firmy. W odróżnieniu od europejskiego standardu, za który uznajemy indywidualizm, jednostkową przedsiębiorczość, dążenie do maksymalizacji korzyści, w Japonii najważniejszym wyznacznikiem jest kolektywizm. Podstawowym aktorem działań społecznych nie jest jednostka, lecz grupa. Relacje zaś, w świetle których rozpatrywane są działania społeczne, dotyczą grup, a nie jednostek.

Sam konfucjanizm opiera się na pięciu relacjach, w większości hierarchicznych. Są to relacje ,jakie występują między ojcem a synem (miłość), między władcą a urzędnikiem (sprawiedliwość), mężem i żoną (szacunek dla ich oddzielnych funkcji), między starszym a młodszym bratem (porządek) i między przyjaciółmi (lojalność)" (Wójcik 2001, s. 356). Są to relacje oparte na powiązanych zobowiązaniach - nie tylko strona podporządkowana jest winna szacunek partnerowi, lecz także strona dominująca ma obowiązki wobec strony podporządkowanej. Jedynie relacja między przyjaciółmi, którą rządzić ma zasada lojalności, jest relacją równorzędnych partnerów. Ogromny szacunek dla stojących wyżej w hierarchii wpływa także na sposób organizacji przedsiębiorstwa.

Firma traktowana jest jak rodzina. Relacje nie są oparte na stosunku pracy, gdyż umowa o pracę nie jest najważniejszym elementem wiążącym pracownika i reprezentującego firmę pracodawcę. Ważniejsze jest wzajemne zaufanie i szacunek oraz świadomość pracownika, że 
wchodząc w szeregi firmy staje się członkiem rodziny i pracuje na rzecz dobra ogółu. Niezależnie od wykształcenia musi przejść przez wszystkie szczeble kariery, by trafić na stanowisko, do którego aspiruje. Etyka pracy, którą prezentują Japończycy, podobnie jak cała struktura społeczna, zwana przez nich samych shigarami, jest oparta na sieci delikatnych powiązań. Świadomość, że cała struktura może się rozpaść, gdy jeden z budujących ją elementów zawiedzie, sprawia, że każdy stara się zająć odpowiednie miejsce i dobrze wypełniać powierzoną mu rolę, niezależnie od tego, jaka by ona była. Indywidualizm nie ma tu większego znaczenia. W półbiograficznej książce $Z$ pokora i uniżeniem, Amelie Nothomb, która opisuje swoje doświadczenia z rocznej pracy w japońskiej korporacji podkreśla, że jednostka w firmie znaczy mniej niż zero. Dopiero jako część grupy zaczyna znaczyć i ma prawo do szacunku. To relacja, w którą wchodzi, określa jej wartość. W taki też sposób pracownik traktowany jest przez pracodawcę. Nie jest indywidualnością, lecz członkiem grupy, której powierzono określone obowiązki.

Tak jak ród, z którego pochodzi Japończyk, do pewnego momentu określa to, kim jest, tak współcześnie firma, czyli organizm, którego jest częścią, decyduje o jego pozycji społecznej. Już nie rodzina, lecz firma staje się współcześnie tym, co określa tożsamość jednostki. Mowa nawet o tak zwanej „mentalności kaisha”, czyli przedkładaniu firmy ponad rodzinę - to jej poświęca się najwięcej czasu, co często uniemożliwia, szczególnie kobietom, założenie rodziny, kariera i życie rodzinne stoją bowiem w absolutnej sprzeczności. Dla mężczyzn życie staje się przedsiębiorstwem. Nie jest bowiem możliwe, by rodzinie poświęcać wystarczająco dużo czasu i uwagi, gdy dojazdy do pracy zajmują około 5 godzin dziennie, a resztę stanowią godziny pracy. Bardzo częstym rozwiązaniem są tzw. hotele kapsułowe, w których spędzają noc ci biznesmeni, którzy nie wracają po pracy do domów. Kobiety - najczęściej porzucające pracę w momencie wyjścia za mąż i coraz częściej powracające do niej, gdy dzieci się usamodzielniają - spędzają życie w samotności. Konsekwencją życia w zgodzie z „mentalnością kaisha", któremu się podporządkowują, jest choroba cywilizacyjna zwana syndromem męża emeryta. Kiedy bowiem pracujący salaryman, zwany również „samurajem z teczką" (bo tak popularnie nazywa się pracowników japońskich korporacji), przechodzi na emeryturę, w domu, który do tej pory zamieszkiwała tylko kobieta, zachodzą zasadnicze zmiany. Pojawia się ktoś obcy, kogo kobieta widywała rzadko i z kim niewiele ją łączy, mimo długiego małżeńskiego stażu. Pojawiają się objawy psychosomatyczne, konieczne są wizyty u terapeutów pomagających zarówno samym kobietom, jak i parom. Często jedynym wyjściem jest rozstanie. Nieprzerwanie wzrastający od kilkunastu lat odsetek rozwodów jest jedną z cywilizacyjnych konsekwencji wzrostu znaczenia życia zawodowego.

Interesującym aspektem japońskiego rynku pracy i sposobu, w jaki rozumiana jest przedsiębiorczość, jest nieobecność kobiet. W japońskich firmach, podobnie jak w japońskich domach, istnieje zasadniczy i tradycyjny podział ról. „Mam nadzieję, że panna młoda okaże się dobrą żoną i mąż będzie mógł dzięki temu skupić się na pracy w firmie" - to słowa często wypowiadane przez świadka pana młodego w trakcie ceremonii japońskich zaślubin. W doskonały sposób wskazują one miejsce, jakie tradycyjnie powinna zajmować japońska kobieta. Wzorzec ryosaikenbo („dobra żona i mądra matka”), mimo że jest tradycyjny i zwyczajowo wiązany z okresem przed industrializacją Japonii, nadal obowiązuje, lecz uzupełniany jest o obowiązek wspierania męża w jego pracy w firmie. Zajmująca się pozycją kobiety w Japonii Norie Mogi pisze, że choć japońskie firmy uważały poparcie żon za coś niezbędnego i absolutnie koniecznego dla męża, to nie uznawały ich za część siły roboczej. Tradycją w japońskich firmach było, że po wyjściu za mąż pracująca do tej pory kobieta przechodzi na swego rodzaju ,emeryturę małżeńską” - porzuca karierę i zaczyna zajmować 
się domem. Zgodnie z tradycją nadrzędnym celem kobiet nie jest bowiem podążanie ścieżką kariery, lecz znalezienie dobrego męża i stanie się ryosaikenbo. Stąd obowiązujący przez większość XX w. standard - zatrudnianie jako urzędniczek (a także office lady) młodych, niezamężnych kobiet, których płaca z założenia miała być niska, a czas pracy - krótki. Ten wzorzec zmieniał się jednak z upływem lat. Wielu badaczy, w tym Mogi, uważa, że pozycja kobiet zmieniła się wraz z wejściem na rynek pracy pokolenia powojennego wyżu demograficznego. Amerykańska socjolog Alice Lam podkreśla, że ogromny przyrost zatrudnienia kobiet $\mathrm{w}$ tzw. white-collar jobs (zawodach biurowych, w tym office lady) związany jest zarówno z przemianami struktury japońskiego przemysłu, jak i ze wzrostem poziomu wykształcenia kobiet. W okresie dynamicznych zmian w Japonii odsetek kobiet z wyższym wykształceniem wzrósł w latach 1970-1990 ponaddwukrotnie - z 17,7\% w 1970 r. do 37,4\% w $1990 \mathrm{r}$. W tym samym czasie odsetek mężczyzn z wyższym wykształceniem zmieniał się od 29,3\% w 1970 r. do 35,1\% w 1990 r. (Lam 1992).

Mimo korzystnych, choć rozciągniętych w czasie zmian, japoński ideał „człowieka sukcesu” nadal dotyczy przede wszystkim pracowników płci męskiej. Praktycznie niemożliwe jest bowiem pogodzenie kobiecego wzorca ryosaikenbo z modelem kariery, jaki oferują japońskie korporacje. Częste transfery pomiędzy oddziałami firmy, oczekiwania dotyczące uczestnictwa w spotkaniach pracowników po godzinach pracy, napięty harmonogram nadgodzin, bardzo długie w porównaniu z Europą i Stanami Zjednoczonymi godziny pracy, niechętne udzielanie urlopów - to tylko kilka z wymagań stawianych Japończykom wykonującym pracę salarymanów, którzy (w domyśle) mają żony zajmujące się sprawami domu i rodziny (Roberts 1994).

Ciekawym wymogiem stawianym japońskim pracownikom jest oczekiwanie przełożonych i innych pracowników dotyczące wspólnego spędzania czasu po godzinach pracy. Mają one służyć utrwalaniu związków ze społecznością. Przyjmują postać wspólnych wyjść po pracy na kieliszek sake i innych trunków, które dość szybko rozwiązują pracownikom języki i umożliwiają swobodniejszą niż w biurze wymianę myśli. Dorota Hałasa, polska dziennikarka i korespondentka z Japonii pisze, że praca i utrwalanie więzów współpracy między pracownikami po godzinach pracy w biurze biorą górę nad związkami z rodziną (Hałasa 2004). Żona, która wie, jak ,zająć właściwe miejsce", nie śmie poprosić męża o wcześniejszy powrót do domu. Aby zyskać akceptację grupy, pracownik powinien poprzez wspólne spotkania po pracy udowodnić przyjazne nastawienie do jej członków. Zbyt częste i nieuzasadnione unikanie wspólnych spotkań interpretowane jest jako akt wrogości i może się spotkać z ostracyzmem.

Podobnie jak w przypadku innych relacji hierarchicznych wywodzących się z etyki konfucjańskiej, także relacja menedżer - szeregowy pracownik oparta jest na zasadzie wzajemności. Szefowie działów „opiekujący się” podległymi im pracownikami zobowiązani są do zapraszania podwładnych na kolację do restauracji lub własnego domu przynajmniej raz w miesiącu. Także badania nad kulturami organizacyjnymi prowadzone przez Geerta i Gerta Jana Hofstede sugerują, że w społeczeństwach kolektywistycznych (do jakich autorzy zaliczają Japonię) miejsce pracy jest zazwyczaj dla pracownika źródłem silnej identyfikacji grupowej i budowania bliskich, niemal rodzinnych relacji w obrębie firmy. Relacje między przełożonym a pracownikiem są postrzegane w kategoriach moralnych. W dużym stopniu przypominają one związki rodzinne, gdyż - jak one - są oparte na wzajemnych zobowiązaniach, gwarantujących bezpieczeństwo w zamian za niekwestionowaną lojalność (Hofstede 2007). Nowi pracownicy często są rekrutowani spośród członków rodziny już zatrudnionych osób, jako że decydującym kryterium przy wyborze kandydatów jest poręczenie. Preferowane są osoby spokrewnione z pracodawcą oraz osoby z rodzin innych pracowników. Uważa się, że zatrudnienie osoby z określonymi koligacjami rodzinnymi zmniejsza ryzyko dokonania błędnego wyboru, ponadto 
daje gwarancję, że nad prawidłowym zachowaniem pracownika będzie czuwać nie tylko sam pracodawca, lecz także członkowie rodziny, dbający o zachowanie dobrej reputacji. Wyjątkiem, o którym pisze również Clark w pracy The Japanese Company, są związki małżeńskie. Gdy dwoje pracowników jednej firmy zawrze związek małżeński (shankai kekkon), często jedno z nich musi zmienić pracę. Częściej jednak zdarza się, że to kobieta rezygnuje z dotychczasowej pracy i jedynym połączeniem z firmą, która kiedyś była jej drugą rodziną, staje się mąż. Ponadto mąż, jako lojalny pracownik, nie informuje jej, a nawet zniechęca do pytania o to, jak zmienia się życie firmy, której była częścią (Clark 1971).

Życie podporządkowane przedsiębiorstwu ma liczne ciemne strony. Poświęcenie prywatności $\mathrm{i}$ indywidualizmu oraz wtłoczenie jednostki w ramy firmy ma także strony jasne. Firma jest rodziną, a rodzina nigdy nie porzuca swoich członków. Tak właśnie jest w przypadku japońskiego przedsiębiorstwa. Nierzadko zdarza się, że pracownik zostaje przyjęty do pracy w wyniku osobistych rekomendacji osoby już pracującej w danej firmie. To, co w zachodnim kręgu cywilizacyjnym, najwyżej stawiającym indywidualizm i osobiste zdolności, uchodziłoby za nepotyzm, w Japonii jest normą. Japończyk, poręczając za kogoś, wystawiając mu świadectwo, bierze za niego odpowiedzialność, tak bowiem skonstruowane są relacje społeczne. Osoba brana pod skrzydła musi w tej sytuacji zachować twarz, by nie narazić na szwank honoru poręczyciela. To relacja wzajemnych zobowiązań. Niepisaną zasadą jest to, że przyjętym do pracy jest się zazwyczaj raz na całe życie. Dożywotnie zatrudnienie pracowników było do pewnego momentu tradycyjnym i powszechnie obowiązującym sposobem organizacji japońskich przedsiębiorstw. Pracownik obdarzany zaufaniem i zatrudniany na czas nieokreślony - co oznaczało związanie z firmą aż do momentu przejścia na emeryturę - jest tym, w którego warto inwestować. W przypadku pracownika, który jest na stałe związany z firmą, szkolenia, treningi i podnoszenie kwalifikacji są bardziej opłacalne dla przedsiębiorstwa. Także pracownikowi bardziej opłaca się pozostać związanym z firmą na długi czas, gdyż zarobki w japońskim przedsiębiorstwie wzrastają wraz ze stażem, co znacząco wpływa też na pozycję rodziny pracownika.

Należy jednocześnie podkreślić, że umowa o pracę nie jest w tym wypadku wcale konieczna. Relacja pracodawca - pracownik opiera się bowiem na tradycyjnym, nieformalnym zobowiązaniu, które dla obydwu stron jest oczywiste i wiążące, choć elastyczne i zmienne w czasie. Taki jest japoński stosunek do prawa, którego częścią są pisemne umowy i zobowiązania. Japońskie traktaty, inaczej niż europejskie, mogą być swobodnie negocjowane w czasie trwania, przy dążeniu do kompromisu przez obydwie strony wchodzące w relację. Zmienność jest tym, co w oczach Japończyków charakteryzuje całość rzeczywistości. Taoistyczny symbol yin-yang, gdzie to, co ciemne, płynnie przechodzi w to, co jasne, sugerujący, że dobro może stać się złem, a bierność przepływa w aktywność w zależności od zmieniających się okoliczności, jest tym, co w doskonały sposób opisuje japoński stosunek do rzeczywistości. W przypadku umowy zmienność w czasie jest dla Japończyków czymś naturalnym. Sama umowa nie jest jednak konieczna, gdyż prawo nie jest uznawane za sankcję potrzebną w przypadku kultur wstydu, wśród których sytuuje się również Japonia. Honor i moralność są tam najważniejszym źródłem etyki i zasad postępowania. Wstyd, utrata twarzy i wina, której nie da się zmazać, odróżniają kultury wstydu od kultur winy, które dają swoim członkom możliwość oczyszczenia, a dzięki pokucie - możliwość przywrócenia spokoju sumienia.

Odejście z pracy następuje najczęściej w wieku emerytalnym. Gdy jednak pracownik nie spełnia pokładanych w nim nadziei i źle wywiązuje się z obowiązków, istnieją dwie możliwości rozwiązania niepisanej umowy. Japońskie korporacje praktycznie nigdy nie zwalniają swoich pracowników. Jeżeli sam pracownik nie złoży wymówienia, regułą jest skierowane w jego stronę yamete morau, czyli prośby o odejście z własnej woli lub kibo taishoku saseru, 
nakłanianie do złożenia dymisji (Clark 1971). Tego typu prośby odwołują się do honoru pracownika, który - by zachować twarz - rezygnuje z pracy. Walka o pozostanie na stanowisku zdarza się bardzo rzadko; ryzyko narażenia się na śmieszność i wstyd są tym, co z zasady blokuje takie starania. Do zwolnień ze względu na słabe wyniki dochodzi bardzo rzadko, firma nie zwalnia bowiem swoich dzieci. Geert Hofstede w badaniach nad kulturą organizacji stwierdza, że tego typu relacje są najbardziej typowe dla organizacji japońskich, choć należy podkreślić, że dotyczą jedynie pracowników zatrudnionych na stałe, czyli mniej niż połowy ogółu zatrudnionych (Hofstede 2007). Jedynym wyjątkiem są wspomniane już wyżej małżeństwa pomiędzy pracownikami jednej firmy. Gdy zostają zawarte, jeden z małżonków rezygnuje z pracy.

Sama przedsiębiorczość rozumiana może być jako czwarty czynnik produkcji, równie ważny jak praca, ziemia i kapitał. Może być także postrzegana jako zespół cech charakteryzujących przedsiębiorcę. Cechy, którymi przedsiębiorcy powinni być obdarzeni, to umiejętność dostrzegania potrzeb i doskonalenia pomysłów, zdolność do wykorzystywania nadarzających się okazji oraz gotowość do podejmowania ryzyka. W świetle tego drugiego rozumienia pojęcia przedsiębiorczości należy stwierdzić, że Japończycy jednocześnie są i nie są przedsiębiorczy. Są bowiem obdarzeni umiejętnością doskonałego dostosowywania się do zmieniających się warunków, czego dowodzi historia ich narodu. Faktem jest również to, że ciągle doskonalą swoje pomysły. Jeśli jednak chodzi o umiejętność podejmowania ryzyka, napotykamy przeszkodę nie do pokonania.

Model przedsiębiorcy potrafiącego zaryzykować jest zupełnie obcy społeczeństwom Dalekiego Wschodu, wśród nich również Japończykom. Wiąże się to z orientacją długoterminową, charakteryzującą działania azjatyckich przedsiębiorców oraz samych Azjatów. Liczy się inwestowanie w budowę silnej pozycji na rynku, nawet kosztem szybkich, spektakularnych sukcesów. Menedżerowie dysponujący czasem i środkami mogą osobiście przyczyniać się do rozwoju firmy. Niebagatelne znaczenie ma również fakt, że są oni często członkami rodzin. Inaczej jest w firmach działających w ramach kultur o orientacji krótkoterminowej, gdzie nacisk kładzie się na wyniki bieżące. Stanowią one podstawę oceny pracy zarówno władz nadzorczych, jak i menedżerów, znajdują się więc w centrum zainteresowania pracowników wszystkich szczebli. Geert Hofstede podkreśla, że ten stan rzeczy jest uzasadniany wymogami racjonalności. Jest to jednak racjonalność wtórna w stosunku do pierwotnych wyborów kulturowych. Decyzje o krótkiej perspektywie czasowej, czyli te, które najczęściej wiążą się z wynikami finansowymi i maksymalizacją zysków, mogą jednak drogo kosztować, gdy zważy się na ich długodystansowe konsekwencje. Przedsięwzięcia operujące w krótkiej perspektywie czasowej wymagają stałego nadzoru pracy, pospiesznej adaptacji pomysłów oraz niejednokrotnie - szybkiej z nich rezygnacji. Także system doraźnych kar i nagród za osiągane wyniki świadczy o pewnej krótkowzroczności. Działania menedżerów oraz wyniki, jakie osiąga przedsiębiorstwo, są najczęściej konsekwencjami decyzji podejmowanych wiele lat wcześniej przez inne, dawno już niepracujące kadry kierownicze. System jest silny, gdyż kultura sama go reprodukuje, wbrew licznym wewnętrznym sprzecznościom.

Jedną z podstaw tezy o orientacji długoterminowej społeczeństw Dalekiego Wschodu, która decyduje o ich dużym sukcesie gospodarczym, jest hipoteza neokonfucjańska, sformułowana w 1979 r. przez amerykańskiego futurologa, Hermana Kahna. Twierdził on, że sukcesy, jakie w owym czasie odnosiły kraje wschodniej Azji, należy przypisywać wartościom konfucjańskim oraz wspólnym korzeniom leżącym u podstaw kultury krajów Dalekiego Wschodu. Porównując wyniki Kahna z wynikami własnych badań, Hofstede stwierdza, że istnieje znacząca korelacja pomiędzy wzrostem gospodarczym a wskaźnikiem LTO (long 
term orientation - wskaźnik orientacji długoterminowej). Wśród wartości konfucjańskich wyznawanych przez społeczeństwa azjatyckie największe znaczenie mają oszczędność, zapobiegliwość i wytrwałość.

To nastawienie długoterminowe, moralność i honor stawiane wyżej niż prawo, organizacja przedsiębiorstwa przypominająca strukturę rodzinną, a także oparcie relacji na zasadach hierarchicznych i osobistym powiązaniu sprawiają, że japońska przedsiębiorczość zasadniczo różni się od zachodnioeuropejskiej. Nie można pominąć roli państwa, które prowadziło wieloletnią politykę protekcjonizmu i traktowało keizai, czyli wiedzę ekonomiczną, nie jako wiedzę obiektywną, lecz jako swego rodzaju system filozoficzno-moralny, rozumiany jako „kierowanie narodem i przynoszenie ulgi ludziom”. Także powiązania biznesu i polityki, odzwierciedlane przez zjawisko amakudari, czyli podejmowanie pracy w zarządach przedsiębiorstw przez przechodzących na emeryturę funkcjonariuszy państwowej administracji, nie są bez znaczenia. System ten sprzyja zacieśnianiu współpracy między biznesem a biurokracją. Jest równocześnie uważany za warunek sine qua non skutecznej polityki przemysłowej. Te wszystkie cechy również stanowią o specyfice japońskiej przedsiębiorczości.

Podsumowując, należy dodać, że przedsiębiorczość nie jest domeną samych tylko przedsiębiorców. Badania CVS (Chinese Value Survey), przeprowadzone przez Michaela Bonda na próbach azjatyckich studentów wskazują, że wartości związane z umiejętnością podejmowania decyzji są charakterystyczne dla całych społeczeństw, czyli zarówno obecnych, jak i przyszłych przedsiębiorców, a także ich pracowników i rodzin. Wartości konfucjańskie, wśród których oprócz wymienionych wyżej: oszczędności, zapobiegliwości i wytrwałości znajdują się: szacunek dla tradycji, zachowanie twarzy oraz przywiązanie do statusu jako czynnika porządkującego relacje, najwyżej cenią Chińczycy, osobno badani mieszkańcy Hongkongu i Tajwanu. W pierwszej czwórce znaleźli się również mieszkańcy Japonii.

Trafne jest zatem stwierdzenie, że życie Japończyków jest przedsiębiorstwem. Za czasów shogunatu samurajowie w swoim postępowaniu kierowali się kodeksem wojownika zwanym bushido - drogą wojownika, który wpływał także na życie nienależących do arystokracji członków społeczeństwa. Podobnie współcześnie, samurajowie z teczkami oraz ich rodziny, zarówno w pracy, jak i w życiu prywatnym przestrzegają zasad niepisanego kodeksu kaishaindo - drogi pracownika.

\section{Literatura}

1. Clark R., 1971, The Japanese Company, Charles E. Tuttle Company, Tokio.

2. Bilski H., 2002, Japonia - walka o odzyskanie silnej pozycji gospodarczej i finansowej, Narodowy Bank Polski, Warszawa.

3. Hałasa D., 2004, Życie codzienne w Tokio, Wydawnictwo Akademickie DIALOG, Warszawa.

4. Hofstede G., Hofstede G.J., 2007, Kultury i organizacje, Polskie Wydawnictwo Ekonomiczne S.A., Warszawa.

5. Lam A., 1992, Women and Japanese management. Discrimination and reform, Routledge, Londyn -Nowy Jork.

6. Mogi N., 2005, Kobiety w Japonii przeszłości i dniu dzisiejszym [w:] Międzykulturowe i interdyscyplinarne badania feministyczne. Daleki-Bliski Wschód. Wspótczesność i prehistoria, E. Pakszys (red.), Wydawnictwo Naukowe UAM, Poznań.

7. Nothomb A., 2005, Z pokora i uniżeniem, Muza, Warszawa.

8. Roberts G.S., 1994, Staying on the Line. Blue-Collar Women in Contemporary Japan, University of Hawaii Press, Honolulu.

9. Wójcik A., 2001, Konfucjanizm [w:] Filozofia Wschodu, t. 1, B. Szymańska (red.), t. 2, Wybór tekstów, M. Kudelska (red.), Wydawnictwo Uniwersytetu Jagiellońskiego, Kraków. 


\section{Life is kaisha. Towards an Understanding of Japanese Entrepreneurship}

There are a lot of differences between Western and Japanese work culture. A discussion of these differences requires reference to Confucian thinking, for the organization of the kaisha, the Japanese company, is strongly influenced by Far Eastern ethics, morality and understanding of the law. Culture and tradition are also very important in determining the relations between superiors and subordinates, which are organized in a way that resembles family relations. Personal responsibility, long-term commitment, the significance of mutual trust (as opposed to written contract) are some of the qualities that characterize the Japanese labor market. Collectivism and a culture-bound ease the adaptation to changing conditions and they are also important for this matter. Strong personal connections between business and bureaucracy, as well as long-term orientation of business contact, have a decisive role in shaping the way Japanese companies are organized and run. In 19th century Japan, the slogan of the Meiji Era reformists was "wakon yosai", which can be translated as "Japanese spirit, Western science". At that time, Japanese commerce and industry were reformed as well. However, all these changes had to be implemented with respect for the "Japanese ways". The aim of this paper is to describe how these "ways" have formed Japanese entrepreneurship. 